\title{
(+)-Terrein inhibits human hepatoma Bel-7402 proliferation through cell cycle arrest
}

\author{
FENGLI ZHANG, MEIHERIGULI MIJITI, WEI DING, JIALE SONG, YING YIN, WEI SUN and ZHIYONG LI \\ Marine Biotechnology Laboratory, State Key Laboratory of Microbial Metabolism and School of Life \\ Sciences and Biotechnology, Shanghai Jiao Tong University, Shanghai 200240, P.R. China
}

Received October 14, 2014; Accepted December 11, 2014

DOI: $10.3892 /$ or.2015.3719

\begin{abstract}
Hepatoma is a common malignant tumor. Thus, the development of a high-efficacy therapeutic drug for hepatoma is required. In this study, (+)-terrein isolated from the marine sponge-derived Aspergillus terreus $\mathrm{PF}-26$ against cell growth, apoptosis and cell cycle were assessed by MTT and flow cytometry. mRNA array containing 73 cell cycle-related genes and three cell morphology-related genes was generated and its performance evaluated. The cell cycle pathway map was created using the pathview package. The results showed that (+)-terrein inhibited the growth of Bel-7402 cells with alterations in cell morphology and a reduced transcript expression of cell morphology genes (fibronectin, $\mathrm{N}$-cadherin, and vimentin). In addition, flow cytometric analysis revealed that (+)-terrein arrested the Bel-7402 cell cycle without inducing apoptosis. Based on multiple mRNA analysis, the downregulated expression of the CCND2, CCNE2, CDKN1C, $C D K N 2 B, A N A P C, P K M Y T 1, C H E K 2$ and PCNA genes was observed in $10 \mu \mathrm{M}(+)$-terrein-treated Bel-7402 cells ( $>2$-fold and $\mathrm{P} \leq 0.05)$, compared with the controls. Thus, the antiproliferative mechanism of (+)-terrein against Bel-7402 cells may be
\end{abstract}

Correspondence to: $\mathrm{Dr}$ Zhiyong Li, Marine Biotechnology Laboratory, State Key Laboratory of Microbial Metabolism and School of Life Sciences and Biotechnology, Shanghai Jiao Tong University, 800 Dongchuan Road, Minhang, Shanghai 200240, P.R. China

E-mail: zyli@sjtu.edu.cn

Abbreviations: ANAPC5, anaphase-promoting complex subunit 5; Cdk, cyclin/cyclin-dependent kinase; CDKI, Cdk inhibitors; CDKN1C, cyclin-dependent kinase inhibitor $1 \mathrm{C}$; $\mathrm{Ct}$, threshold cycle; DC, dissociation curves; GDC, genomic DNA control; HCC, hepatocellular carcinoma; ink4b, cyclin-dependent kinase 4 ihibitor B; M-CdK, mitotic cyclin-dependent kinase; PCNA, proliferating cell nuclear antigen; SPSS, Statistical Product and Service Solutions; Tm, melting temperature; KEGG, Kyoto Encyclopedia of Genes and Genomes

Key words: (+)-terrein, Aspergillus terreus, human hepatoma Bel-7402, cell proliferation, cell cycle arrest due to the cell cycle arrest by blocking cell cycle gene expression and changing cell morphology.

\section{Introduction}

Hepatocellular carcinoma (HCC) is the most common malignant tumor and the third leading cause of cancer mortality worldwide (1). In China, HCC causes $~ 110,000$ deaths annually (2). Current chemotherapeutic drugs for treating HCC are restricted in their clinical application because of toxicity and low efficacy $(3,4)$. Arsenic trioxide $\left(\mathrm{As}_{2} \mathrm{O}_{3}\right)(1-8 \mu \mathrm{M})$ arrests HCC (HepG2 and SMMC-7721 cells) in the $\mathrm{G}_{2} / \mathrm{M}$ phase (5). However, applications there of are controversial as arsenic compounds exhibit high toxicity. Therefore, developing a novel high-efficacy therapeutic drug for hepatoma is required (4). In 1935, Raistrick and Smith (6) first isolated (+)-terrein from Aspergillus terreus. Terreins with distinct configurations have received considerable attention because of their various substantial bioactivities, including anticancer properties against human cells (7-10).

In antitumor therapy, numerous drugs affect tumorigenesis and tumor growth; however, the key is determining which drugs to exploit in the areas of signal transduction, cell-cycle regulation, apoptosis, telomere biology, necrosis, autophagy, cell senescence and angiogenesis (11-13). Angiogenesis is a critical process for tumor growth, invasion, and metastasis (14). Arakawa et al (7) determined that (-)-terrein inhibited angiogenin secretion in the tumor angiogenesis of androgen-dependent prostate cancer cells. Apoptosis is a form of cell death $(12,15)$. Furthermore, (+)-terrein suppresses the proliferation of breast cancer cells (9), human cervical carcinoma cells (10), and pulmonary tumor cells (8) by inducing an apoptotic mechanism. These results suggested that terreins inhibit tumor cell growth through multiple strategies.

Findings of studies showed that the isolation and production of (+)-terrein (the molecular formula is $\mathrm{C}_{8} \mathrm{H}_{10} \mathrm{O}_{3}$ and the molecular weight is 154; Fig. 1) from the fungus A.terreus PF-26 associated with marine sponges were improved to $\sim 9.07 \mathrm{~g} / 1$ (16-19). However, the activity of (+)-terrein against $\mathrm{HCC}$ and its mechanism remain unknown. In this study, the anticancer activity and mechanism of (+)-terrein against HCC were investigated using the Bel-7402 human hepatoma cell line. The results showed that $(+)$-terrein suppressed Bel-7402 human hepatoma cell growth and proliferation. The 
results indicated that $10 \mu \mathrm{M}(+)$-terrein induced cell cycle arrest in the $\mathrm{G}_{2} / \mathrm{M}$ phase and decreased the cell morphology gene expression of fibronectin, $\mathrm{N}$-cadherin, and vimentin. In addition, the high-throughput platform with parallel detection of multiple mRNAs revealed that treating Bel-7402 cells with $(+)$-terrein substantially altered the expression of cell cycle-related genes. In addition, (+)-terrein did not induce Bel-7402 cell apoptosis, indicating that (+)-terrein inhibits cell proliferation through distinct mechanisms in different cell strains.

\section{Materials and methods}

Reagents and cell lines. (+)-Terrein (Fig. 1) was isolated from A. terreus PF-26, as described previously (18). The isolated (+)-terrein was dissolved in phosphate-buffered saline (PBS, $\mathrm{pH}$ 7.2) for subsequent experiments. The human A549 lung adenocarcinoma epithelial cell line was provided by Dr Wei $\mathrm{Ma}$ (Shanghai Jiao Tong University, China), and the Bel-7402 human hepatoma cell line was obtained from the Cell Bank of the Chinese Academy of Sciences (Shanghai, China). The mentioned cells were cultured in Dulbecco's modified Eagle's medium (DMEM) containing 10\% fetal bovine serum and $100 \mathrm{U} / \mathrm{ml}$ of penicillin and streptomycin. Unless otherwise mentioned, reagents for cell cultures were purchased from Gibco/Invitrogen (New York, Grand Island, USA) and biochemical reagents were obtained from Sigma (New York, NY, USA) or Ameresco (Solon, OH, USA). The cells were grown in a $5 \% \mathrm{CO}_{2}$ atmosphere at $37^{\circ} \mathrm{C}$.

Cell viability and proliferation. An MTT assay [3-(4,5-dimethylthiazol-2-yl)-2,5-diphenyltetrazolium bromide] was performed with $\sim 4 \times 10^{3}$ cells/well in 96 -well plates. The plates containing the cells were incubated at $37^{\circ} \mathrm{C}$ for $24 \mathrm{~h}$, and the cells were treated with (+)-terrein at $37^{\circ} \mathrm{C}$ for $48 \mathrm{~h}$. The protocol was performed using an MTT cell proliferation and cytotoxicity detection kit (KeyGen, Nanjing, China) according to the manufacturer's instructions. Briefly, DMEM was supplemented with $50 \mu \mathrm{l}$ of MTT reagent to each well and incubated at $37^{\circ} \mathrm{C}$ for $4 \mathrm{~h}$. Thereafter, the MTT solution was removed. Following the addition of $150 \mu \mathrm{l}$ of dimethyl sulfoxide (DMSO), the plates were incubated at $37^{\circ} \mathrm{C}$ for 15 min to dissolve the formazan crystals. Absorbance of DMSO extracts was detected at $550 \mathrm{~nm}$ by using an Enspire 2300 microplate reader (PerkinElmer, Foster City, CA, USA). A total of $\sim 3 \times 10^{5}$ cells/well were inoculated in 6-well plates at $37^{\circ} \mathrm{C}$ for $24 \mathrm{~h}$ and treated with (+)-terrein at $37^{\circ} \mathrm{C}$ for $48 \mathrm{~h}$. The PBS-treated cells served as controls. These cells were used to detect cell morphology, cell cycle, apoptosis, and RNA extraction.

Light microscopy analysis. Cells $\left(3 \times 10^{5}\right)$ were cultured in 6-well plates at $37^{\circ} \mathrm{C}$ for $24 \mathrm{~h}$. The Bel-7402 and A549 cells were then treated with $10 \mu \mathrm{M}$ and $10 \mathrm{mM}(+)$-terrein at $37^{\circ} \mathrm{C}$ for $48 \mathrm{~h}$, respectively, and the PBS-treated cells served as controls. The treated cells were used to observe cell morphology and apoptosis. Light microscopy images of the cells were captured using a Nikon Eclipse Ti-inverted microscope and a Nikon digital sight s-Qi1Mc camera (both from Yokohama, Japan). For each surface, three non-overlapping images were selected.

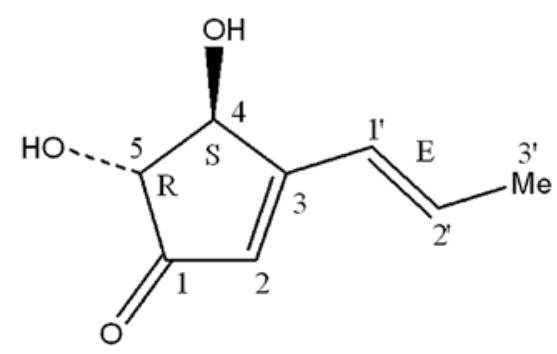

Figure 1. The chemical structure of (+)-terrein.

Cell analysis via flow cytometry. The cells were rinsed once in chilled PBS, digested with $0.25 \%$ trypsin (Gibco), and then resuspended in DMEM and 10\% serum. The suspended cells were centrifuged at $2,000 \mathrm{x} \mathrm{g}$ at $4^{\circ} \mathrm{C}$ for $5 \mathrm{~min}$ and washed once in cold PBS. The cells were stained with Alexa Fluor ${ }^{\circledR}$ 488 Annexin V and PI by using an Alexa Fluor ${ }^{\circledR} 488$ Annexin V/Dead cell apoptosis kit (Invitrogen, New York, USA) according to the manufacturer's instructions. The stained cells were analyzed using flow cytometry (FACSAria-II, BD Biosciences, San Jose, CA, USA).

Gene expression analysis of cell cycle and cell morphology. The Bel-7402 cells treated with $10 \mu \mathrm{M}(+)$-terrein were trypsinized and washed with a PBS buffer. Fifty microliters of single cell suspension was examined using a cell cycle detection kit (KeyGen). The stained cells were analyzed using flow cytometry (FACSAria II).

Total RNA extraction. The Bel-7402 cells treated with (+)-terrein or PBS were trypsinized and washed with a PBS buffer. The cells were collected using centrifugation at $2,000 \mathrm{x} \mathrm{g}$ for $5 \mathrm{~min}$. The cell pellet was then resuspended in RL buffer and centrifuged at $13,000 \mathrm{x}$ g for $5 \mathrm{~min}$. Total RNA was extracted according to the manufacturer's instructions (CWBio, Beijing, China). The purity and concentration of RNA was confirmed by the relative absorbance ratio at $260 / 280 \mathrm{~nm}$ and $260 \mathrm{~nm}$, respectively, by using NanoDrop 2000 (Thermo Fisher Scientific, Waltham, MA, USA).

Reverse transcription. Reverse transcription was performed according to the manufacturer's instructions (Thermo Fisher Scientific). Total RNA (1 $\mu \mathrm{g})$ was mixed with $4 \mu 1$ of a $5 \mathrm{X}$ reaction buffer, $1 \mu \mathrm{l}$ of oligo (dT)18 primer, $1 \mu \mathrm{l}$ of RiboLock RNase inhibitor, $2 \mu 1$ of a $10 \mathrm{mM}$ dNTP mix, $1 \mu \mathrm{l}$ of RevertAid reverse transcriptase $(100 \mathrm{U} / \mu \mathrm{l})$, and then, $\mathrm{ddH}_{2} \mathrm{O}$ was added to increase the volume to $20 \mu 1$. Reverse transcription was performed at $37^{\circ} \mathrm{C}$ for $60 \mathrm{~min}$ and then at $70^{\circ} \mathrm{C}$ for $5 \mathrm{~min}$. The resulting cDNA was stored at $-70^{\circ} \mathrm{C}$ until use.

Polymerase chain reaction (PCR) array and primer design. Table I shows that 73 potential genes involved in the cell cycle were used as the target mRNAs. GAPDH, b2-MG, $\beta$-actin, $R P L 27, H P R T 1$, and $O A Z 1$ were used as housekeeping genes for the control cells. The primers were designed (CT Bioscience Co., Changzhou, China) to cover all of the transcripts of each gene. Table I shows the RefSeq accession IDs. All of the primers had a similar melting temperature (Tm), and it was not 
Table I. Gene information detected by the primers.

\begin{tabular}{|c|c|c|c|}
\hline Gene ID as in PCR array & Symbol & Gene ID & Gene name \\
\hline 1 & ANAPC2 & 29882 & Anaphase promoting complex subunit 2 \\
\hline 2 & ANAPC4 & 29945 & Anaphase promoting complex subunit 4 \\
\hline 3 & ANAPC5 & 51433 & Anaphase promoting complex subunit 5 \\
\hline 4 & BUB1 & 699 & Budding uninhibited by benzimidazoles 1 homolog (yeast) \\
\hline 5 & BUB1B & 701 & Budding uninhibited by benzimidazoles 1 homolog $\beta$ (yeast) \\
\hline 6 & BUB3 & 9184 & Budding uninhibited by benzimidazoles 3 homolog (yeast) \\
\hline 7 & CCNE1 & 898 & Cyclin E1 \\
\hline 8 & CCNE2 & 9134 & Cyclin E2 \\
\hline 9 & CCND1 & 595 & Cyclin D1 \\
\hline 10 & CCND2 & 894 & Cyclin D2 \\
\hline 11 & CCND3 & 896 & Cyclin D3 \\
\hline 12 & $\mathrm{CCNH}$ & 902 & Cyclin H \\
\hline 13 & CDC16 & 8881 & Cell division cycle 16 homolog (S. cerevisiae) \\
\hline 14 & CDC20 & 991 & Cell division cycle 20 homolog (S. cerevisiae) \\
\hline 15 & CDC23 & 8697 & Cell division cycle 23 homolog (S. cerevisiae) \\
\hline 16 & CDC25A & 993 & Cell division cycle 25 homolog A (S. pombe) \\
\hline 17 & CDC25B & 994 & Cell division cycle 25 homolog B (S. pombe) \\
\hline 18 & CDC25C & 995 & Cell division cycle 25 homolog C (S. pombe) \\
\hline 19 & CDC26 & 246184 & Cell division cycle 26 homolog ( . cerevisiae) \\
\hline 20 & $\mathrm{CDC} 27$ & 996 & Cell division cycle 27 homolog (S. cerevisiae) \\
\hline 21 & CDC6 & 990 & Cell division cycle 6 homolog (S. cerevisiae) \\
\hline 22 & CDC7 & 8317 & Cell division cycle 7 homolog (S. cerevisiae) \\
\hline 23 & CDK4 & 1019 & Cyclin-dependent kinase 4 \\
\hline 24 & CDK6 & 1021 & Cyclin-dependent kinase 6 \\
\hline 25 & CDK7 & 1022 & Cyclin-dependent kinase 7 \\
\hline 26 & CDKN1B & 1027 & Cyclin-dependent kinase inhibitor 1B (p27, Kip1) \\
\hline 27 & CHEK1 & 1111 & Checkpoint kinase 1 \\
\hline 28 & CHEK2 & 11200 & Checkpoint kinase 2 \\
\hline 29 & E2F1 & 1869 & E2F transcription factor 1 \\
\hline 30 & E2F2 & 1870 & E2F transcription factor 2 \\
\hline 31 & E2F3 & 1871 & E2F transcription factor 3 \\
\hline 32 & HDAC1 & 3065 & Histone deacetylase 1 \\
\hline 33 & MAD2L1 & 4085 & MAD2 mitotic arrest deficient-like 1 (yeast) \\
\hline 34 & MAX & 4149 & MYC-associated factor X \\
\hline 35 & MCM2 & 4171 & Minichromosome maintenance complex component 2 \\
\hline 36 & MCM3 & 4172 & Minichromosome maintenance complex component 3 \\
\hline 37 & MCM4 & 4173 & Minichromosome maintenance complex component 4 \\
\hline 38 & MCM5 & 4174 & Minichromosome maintenance complex component 5 \\
\hline 39 & MCM6 & 4175 & Minichromosome maintenance complex component 6 \\
\hline 40 & MCM7 & 4176 & Minichromosome maintenance complex component 7 \\
\hline 41 & ORC1L & 4998 & Origin recognition complex, subunit 1 \\
\hline 42 & ORC2L & 4999 & Origin recognition complex, subunit 2 \\
\hline 43 & ORC6L & 23594 & Origin recognition complex, subunit 6 \\
\hline 44 & PCNA & 5111 & Proliferating cell nuclear antigen \\
\hline 45 & PKMYT1 & 9088 & Protein kinase, membrane-associated tyrosine/threonine 1 \\
\hline 46 & RB1 & 5925 & Retinoblastoma 1 \\
\hline 47 & RBL1 & 5933 & Retinoblastoma-like 1 (p107) \\
\hline 48 & SKP2 & 6502 & S-phase kinase-associated protein 2, E3 ubiquitin protein ligase \\
\hline 49 & SMC1A & 8243 & Structural maintenance of chromosomes 1A \\
\hline 50 & TOP2A & 7153 & Topoisomerase (DNA) II $\alpha 170 \mathrm{kDa}$ \\
\hline 51 & TP53 & 7157 & Tumor protein p53 \\
\hline 52 & TFDP1 & 7027 & Transcription factor Dp-1 \\
\hline
\end{tabular}


Table I. Continued.

\begin{tabular}{lcrl}
\hline Gene ID as in PCR array & Symbol & Gene ID & \\
\hline 53 & WEE1 & 7465 & WEE1 homolog $($ S. pombe $)$ \\
54 & & & $\begin{array}{l}\text { Tyrosine 3-monooxygenase/tryptophan 5-monooxygenase activation } \\
\text { Protein, } \varepsilon \text { polypeptide }\end{array}$ \\
55 & YWHAE & 7531 & Cyclin-dependent kinase inhibitor 2A \\
56 & CDKN2A & 1029 & Cyclin-dependent kinase inhibitor 2B (p15, inhibits CDK4) \\
57 & CDKN2B & 1030 & Proteasome (prosome, macropain) 26S subunit, non-ATPase, 9 \\
58 & PSMD9 & 5715 & Prome \\
59 & CDKN1C & 1028 & Cyclin-dependent kinase inhibitor 1C (p57, Kip2) \\
60 & CDC2 & 983 & Cyclin-dependent kinase 1 \\
61 & CCNB2 & 9133 & Cyclin B2 \\
62 & CCNB1 & 891 & Cyclin B1 \\
63 & CDKN1A & 1026 & Cyclin-dependent kinase inhibitor 1A (p21, Cip1) \\
64 & CDK2 & 1017 & Cyclin-dependent kinase 2 \\
65 & CCNA1 & 8900 & Cyclin A1 \\
66 & CCNA2 & 890 & Cyclin A2 \\
67 & MYC & 4609 & V-myc myelocytomatosis viral oncogene homolog (avian) \\
68 & CDKN2C & 1031 & Cyclin-dependent kinase inhibitor 2C (p18, inhibits CDK4) \\
69 & GAPDH & 2597 & Glyceraldehyde-3-phosphate dehydrogenase \\
70 & ACTB & 60 & Actin, $\beta$ \\
71 & B2M & 567 & $\beta$-2-microglobulin \\
72 & HPRT1 & 3251 & Hypoxanthine phosphoribosyltransferase 1 \\
73 & OAZ1 & 4946 & Ornithine decarboxylase antizyme 1 \\
\hline
\end{tabular}

located in the genomic repetitive regions. The primers were selected based on criteria such as a typical amplification curve and single peak from the post-PCR melting curve. FN, gene ID 2335; N-cadherin, gene ID 1000; and vimentin, gene ID 7431 which are involved in cell morphology were also investigated.

Real-time PCR analysis. Each cDNA was diluted to $1 \mathrm{ml}$ with $\mathrm{ddH}_{2} \mathrm{O}$ and mixed with $1 \mathrm{ml}$ of $2 \mathrm{X}$ SYBR Premix Ex Taq $^{\mathrm{TM}}$ (Takara, Dalian, China). Twenty microliters of this mixture was added to each well of a 96-well PCR array, except for genomic DNA control (GDC). The 96-well PCR plates containing gene primers were prepared by the CT Bioscience Company (Changzhou, China). The sealed PCR plate was loaded in an Eppendorf Realplex 4S (Hamburg, German). The PCR was performed under the following conditions: $95^{\circ} \mathrm{C}$ for $5 \mathrm{~min}, 40$ cycles at $95^{\circ} \mathrm{C}$ for $15 \mathrm{sec}, 60^{\circ} \mathrm{C}$ for $15 \mathrm{sec}$, and $72^{\circ} \mathrm{C}$ for $20 \mathrm{sec}$. The melting curve procedure $\left(95^{\circ} \mathrm{C}\right.$ for $15 \mathrm{sec}, 60^{\circ} \mathrm{C}$ for $15 \mathrm{sec}$, and $95^{\circ} \mathrm{C}$ for $15 \mathrm{sec}$ ) was implemented to analyze the PCR specificity. Dissociation curves (DC) and melting temperatures $(\mathrm{Tm})$ were recorded. Relative changes in gene expression were calculated using the threshold cycle $(\mathrm{Ct})$ method (20). The formula used is presented as follows: $\mathrm{n}$-fold change $=2^{-\Delta \Delta \mathrm{Ct}}=(\mathrm{Ct}$ target gene $-\mathrm{Ct}$ internal control gene) treated sample - (Ct target gene - Ct internal control gene) control sample.

Statistical and pathway analysis. Statistical product and service solutions (SPSS ver. 13.0) was used for the data analysis. All of the experiments were conducted in duplicate. The results are presented as mean \pm SD (standard deviation) unless otherwise specified. The P-values were two-tailed. $\mathrm{P} \leq 0.05$ was considered to indicate a statistically significant difference. The cell-cycle pathway is a highly regulated process that incorporates three major checkpoints including the participation of several genes (21). The functional pathways associated with the set of differentially expressed genes were analyzed using the Kyoto Encyclopedia of Genes and Genomes (KEGG) analysis (http://www.kegg.jp/kegg/pathway.html). Differentially expressed gene with $>2$-fold change were analyzed in the cell-cycle pathway (22). The pathway map was created using the Pathview ${ }^{\mathrm{TM}}$ package (23).

\section{Results}

(+)-Terrein reduces cell growth. The in vitro toxicity of (+)-terrein against Bel-7402 cells and the A549 human lung adenocarcinoma epithelial cell line was evaluated using the MTT method [3-(4,5-dimethylthiazol-2-yl)-2,5-diphenyltetrazolium bromide] to determine the potential inhibitory concentration. MTT analysis revealed that $(+)$-terrein inhibited cell viability and proliferation in a concentration-dependent manner. Fig. 2A shows the inhibition of Bel-7402 cells at various (+)-terrein concentrations. $\mathrm{The} \mathrm{IC}_{50}$ (half maximal inhibitory concentration) value of Bel-7402 was calculated as $11.63 \mu \mathrm{M} \pm 0.02$. The dose-dependent inhibition of Bel-7402 indicated that $1 \mu \mathrm{M}(+)$-terrein was non-toxic and $10 \mu \mathrm{M}$ $(+)$-terrein was cytotoxic and associated with a survival rate of $57 \%$. The survival rate of the Bel-7402 cells treated with 

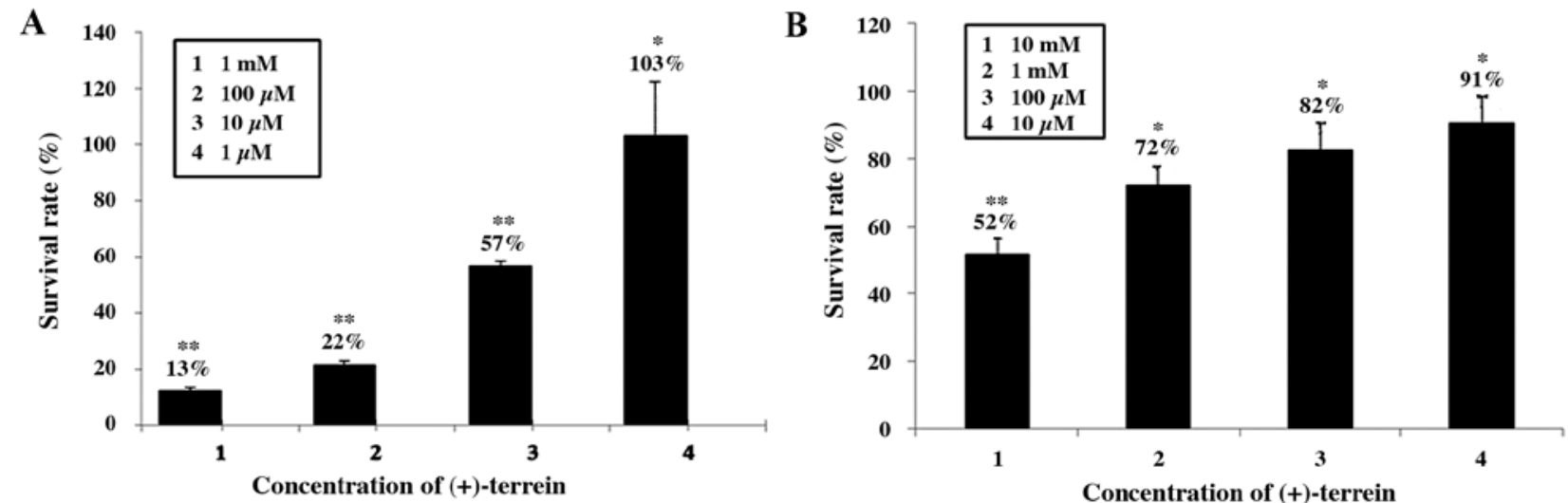

Figure 2. Effect of (+)-terrein on cell viability and proliferation. (A) Effect of (+)-terrein on cell viability and proliferation of Bel-7402 cells. (B) Effect of $(+)$-terrein on cell viability and proliferation of A549 cells. Bel-7402 and A549 cells were treated with (+)-terrein at various concentrations for 48 h. Viability and proliferation of the cells were examined using the MTT method, and the cell survival rate (\%) was calculated. Average values derived from three independent experiments shown as mean \pm standard deviations. " Significant difference from control $(\mathrm{P}<0.05) .{ }^{* *}$ Significant difference from control $(\mathrm{P}<0.01)$.
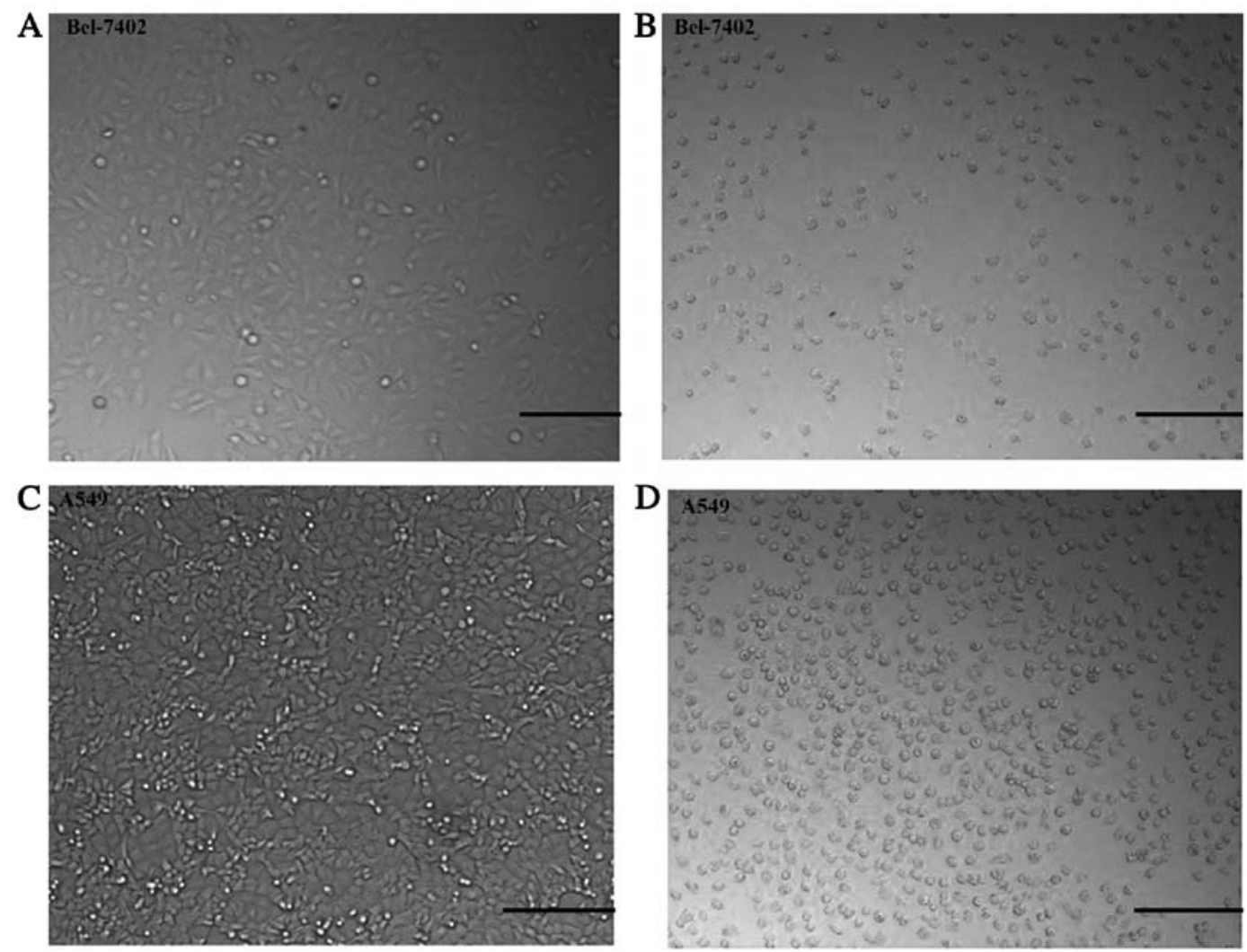

Figure 3. Effect of (+)-terrein on cell morphology of Bel-7402 and A549 cells. Bel-7402 and A549 cells were treated with $10 \mu \mathrm{M}$ and $10 \mathrm{mM}(+)$-terrein for $48 \mathrm{~h}$, respectively. Bel-7402 and A549 cells not treated with (+)-terrein served as controls. Bars under each panel represent $50 \mu \mathrm{m}$.

$100 \mu \mathrm{M}$ and $1 \mathrm{mM}(+)$-terrein exhibited inhibitory activities of $\sim 22$ and $13 \%$, respectively. A low dose of (+)-terrein did not substantially affect the A549 cells. As indicated in Fig. 2B, $(+)$-terrein at various concentrations induced inhibitory activity against the A549 cells. (+)-Terrein at concentrations of $10 \mu \mathrm{M}, 100 \mu \mathrm{M}$, and $1 \mathrm{mM}$ exhibited weak inhibitory activity, and the survival rate of the treated cells was 91,82 , and $72 \%$, respectively. Moreover, (+)-terrein at $10 \mathrm{mM}$ was cytotoxic to A549 cells, and the survival rate of the treated cells was $52 \%$.
(+)-Terrein induces cell morphology change. We observed a marked phenomenon regarding cell morphology alterations when cells were treated with (+)-terrein. Morphological changes in the Bel-7402 cells exposed to $10 \mu \mathrm{M}(+)$-terrein and in the A549 cells exposed to $10 \mathrm{mM}(+)$-terrein for $48 \mathrm{~h}$ were examined using light microscopy (Fig. 3). The Bel-7402 cell morphology alterations were from epithelial-like to spherical, when the cells were treated with $10 \mu \mathrm{M}(+)$-terrein (Fig. 3A and B). The morphological changes from epithelial-like to spherical of the A549 cells exposed to $10 \mathrm{mM}(+)$-terrein for 
Table II. Downregulated expression of cell morphology genes in the Bel-7402 cells treated with (+)-terrein.

\begin{tabular}{lclc}
\hline Gene name & Gene ID & \multicolumn{1}{c}{ Primers } & Expression fold \\
\hline FN (fibronectin) & 2335 & F, FN1: 5'-AACCTCGGCTTCCTCCATAA-3' & -3.61 \\
& & R, FN1: 5'-AACAGTGGGAGCGGACCTA-3' & -2.05 \\
VIM (vimentin) & 7431 & F, VIM: 5'-GCCAACCGGAACAATGAC-3' & -2.39 \\
& \multirow{2}{*}{1000} & R, VIM: 5'-GTGAGGGACTGCACCTGTCT-3' & F, CDH2: 5'-CTAACCCGTCGTTGCTGTTT-3' \\
& & R, CDH2: 5'-ACAGAATCAGTGGCGGAGAT-3' & \\
\hline
\end{tabular}

The Bel-7402 cells were treated with $10 \mu \mathrm{M}(+)$-terrein for $48 \mathrm{~h}$. Each value is the mean of three independent experiments. P $\leq 0.05$ and were statistically significant. F, forward; R, reverse.

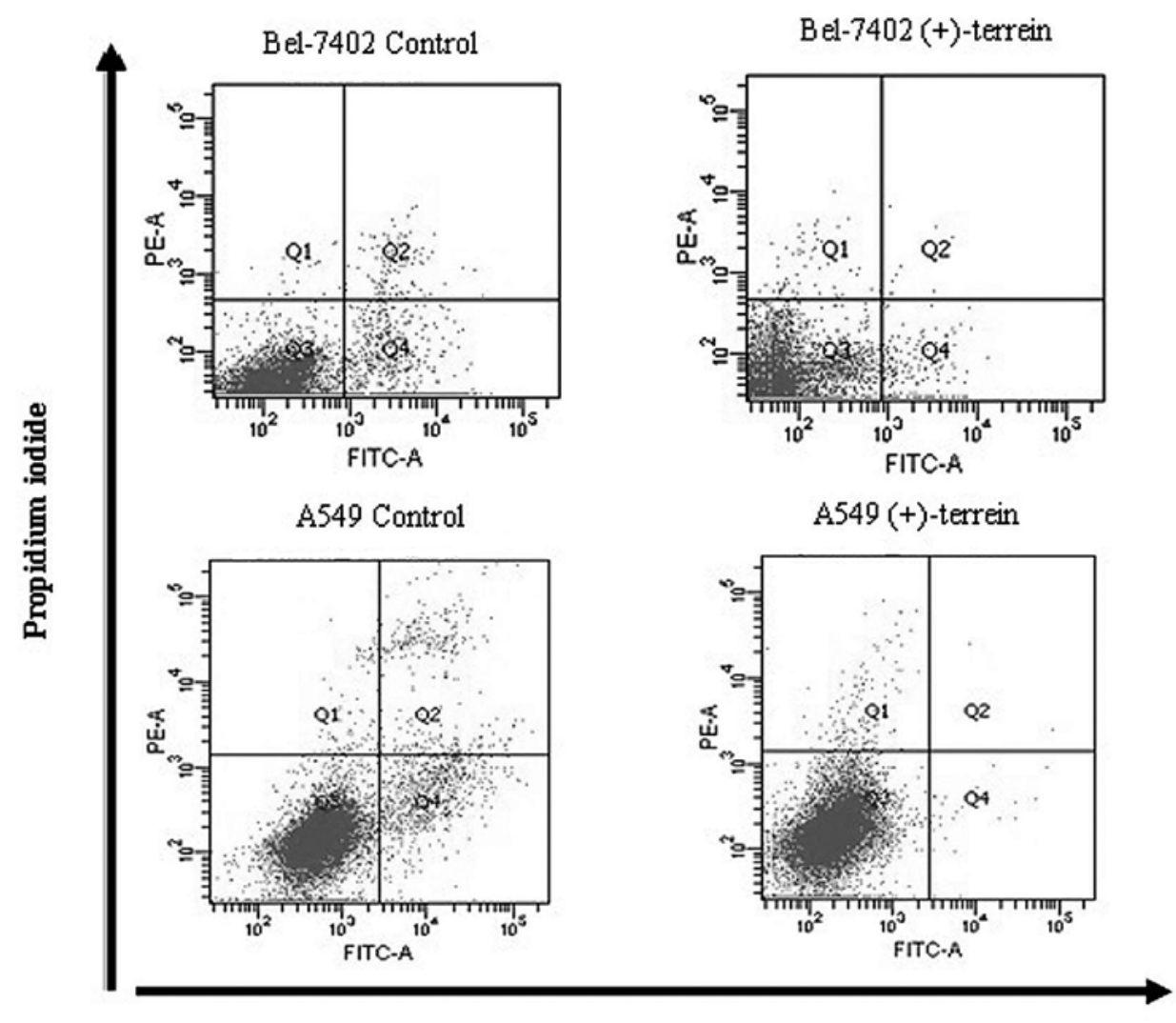

\section{Annexin V}

Figure 4. (+)-Terrein induced cell apoptosis and necrosis. Bel-7402 and A549 cells were treated with $10 \mu \mathrm{M}$ and $10 \mathrm{mM}(+)$-terrein for $48 \mathrm{~h}$, respectively. Apoptosis and necrosis were monitored using Annexin V/PI analysis. Viable cells were Annexin V/PI-negative $\left(\mathrm{Q}_{3}\right.$ quadrant). Early apoptotic cells were Annexin V-positive and PI-negative $\left(\mathrm{Q}_{4}\right.$ quadrant). Late apoptotic and necrotic cells were in the $\mathrm{Q}_{1}$ and $\mathrm{Q}_{2}$ quadrants, respectively. Each bar is the mean $\pm \mathrm{SD}$ of five independent experiments.

$48 \mathrm{~h}$ were examined using light microscopy (Fig. 3C and D). However, $10 \mu \mathrm{l}$ of (+)-terrein did not significantly affect the morphology of A549 cells (data not shown). The cells were adherent, and all of the experiments were repeated at least five times.

The cell morphology gene (FN, N-cadherin, and vimentin) expression of the Bel-7402 cells treated with $10 \mu \mathrm{M}(+)$-terrein was investigated. The results showed that the gene expression of FN, N-cadherin, and vimentin decreased -3.61-, -2.39-, and -2.05 -fold, respectively, compared with the control (Table II).
(+)-Terrein inhibits cell apoptosis and necrosis. To determine whether this reduction in cell growth induced by (+)-terrein was mediated by apoptosis, flow cytometric analysis was performed using PI and Annexin-V staining. The results indicated that the apoptotic levels of Bel-7402 and A549 cells treated with $(+)$-terrein $(10 \mu \mathrm{M}$ and $10 \mathrm{mM})$ did not increase (Fig. 4), but the number of cells treated with (+)-terrein was less than that of the control cells, according to cell counting (data not shown). The mean percentage \pm SD $(n=3)$ of early apoptosis for the Bel-7402 and A549 control cells was 
Table III. (+)-Terrein induced cell apoptosis and necrosis.

\begin{tabular}{llcrr}
\hline & \multicolumn{2}{c}{ Apoptosis (\%) } & \multicolumn{2}{c}{ Necrosis (\%) } \\
\cline { 2 - 4 } Cells & Control & Treated cells & Control & Treated cells \\
\hline Bel-7402 & $5.33 \pm 1.05$ & $2.26 \pm 0.50$ & $1.77 \pm 0.61$ & $0.83 \pm 0.23$ \\
A4549 & $6.17 \pm 0.93$ & $0.53 \pm 0.31$ & $5.43 \pm 2.55$ & $1.93 \pm 1.07$ \\
\hline
\end{tabular}

Early apoptotic cells (\%) were decreased after treatment with (+)-terrein at $10 \mu \mathrm{M}$ to Bel-7402 or at $10 \mathrm{mM}$ to A549 for $48 \mathrm{~h}$. Cells not treated with (+)-terrein served as controls. Late apoptotic and necrotic cells (\%) were decreased after treatment with (+)-terrein at $10 \mu \mathrm{M}$ to Bel-7402 or at $10 \mathrm{mM}$ to $\mathrm{A} 549$ for $48 \mathrm{~h}$. Each value is the mean $\pm \mathrm{SD}$ of five independent experiments.

Table IV. Effect of (+)-terrein on the cell cycle of the Bel-7402 cells.

\begin{tabular}{lccr}
\hline Sample & $\mathrm{G}_{0} / \mathrm{G}_{1}(\%)$ & $\mathrm{S}(\%)$ & $\mathrm{G}_{2} / \mathrm{M}(\%)$ \\
\hline Control & $59.91 \pm 2.8$ & $35.29 \pm 2.1$ & $4.8 \pm 0.53$ \\
Treated cells $(10 \mu \mathrm{M})$ & $56.88 \pm 3.5$ & $35.26 \pm 2.8$ & $7.36 \pm 0.27$ \\
\hline
\end{tabular}

The Bel-7402 cells were treated with (+)-terrein at $10 \mu \mathrm{M}$ for $48 \mathrm{~h}$. Cells not treated with (+)-terrein served as controls. Each value is the mean \pm SD of three independent experiments.

$5.33 \pm 1.05$ and $6.17 \pm 0.93$, respectively, but that for the Bel-7402 and A549 cells after treatment with (+)-terrein for $48 \mathrm{~h}$ was $2.26 \pm 0.50$ and $0.53 \pm 0.31$, respectively (Table III). Fig. 4 shows that (+)-terrein at $10 \mu \mathrm{M}$ and $10 \mathrm{mM}$ inhibited early apoptosis. As indicated in Table III, the mean percentage \pm SD $(n=3)$ of late apoptosis and necrosis for the Bel-7402 and A549 control cells was $1.77 \pm 0.61$ and $5.43 \pm 2.55$, respectively, but that for the Bel-7402 and A549 cells following treatment with (+)-terrein for $48 \mathrm{~h}$ was $0.83 \pm 0.23$ and $1.93 \pm 1.07$, respectively (Table III). Based on these results, (+)-terrein inhibited late cell apoptosis and necrosis (Fig. 4). Standard deviation was larger than the average deviation; however, for every independent experiment, the percentage value (\%) of apoptosis and necrosis in the treated Bel-7402 and A549 cells was lower than that in the control cells.

Effect of (+)-terrein on Bel-7402 cell cycle. Cell proliferation depends on the specific progression of the cell cycle (21). Thus, the cell cycle was analyzed to investigate the anti-proliferative mechanism of (+)-terrein against Bel-7402 cells. Provided the influence of (+)-terrein on A549 occurs at an exceedingly high concentration (>mmol), the anti-proliferative mechanism of (+)-terrein against A549 was not examined. When the Bel-7402 cells were treated with $10 \mu \mathrm{M}(+)$-terrein for $48 \mathrm{~h}$, the proportion of the cells in the $G_{0} / G_{1}$ and $S$ phases was reduced, whereas the proportion of cells in the $\mathrm{G}_{2} / \mathrm{M}$ phase was increased (Table IV). This result suggested that the cell cycle was arrested by (+)-terrein. Thus, (+)-terrein might decrease Bel-7402 cell growth by inducing cell cycle arrest.

Effect of (+)-terrein on cell-cycle regulators. In this study, high-throughput gene expression analysis of 73 genes was performed (Table I). Cell cycle-related gene expression was performed by comparing the gene expression between cDNA samples of (+)-terrein-treated Bel-7402 cells and control cells. Melting curve analysis was used to assess the specificity of the array. A single product peak observed from each reaction without secondary products indicated a high specificity of PCR assay (data not shown). A subset of differentially expressed genes involved in the cell cycle was selected from all the microarray data by performing initial filtration of the P-value ( $\mathrm{P} \leq 0.05)$ and expression level $(>2$-fold) of the $10 \mu \mathrm{M}$ (+)-terrein-treated cells. The cell-cycle scheme from the KEGG database (http://www.kegg.jp/kegg/pathway.html) was presented. Downregulated genes were labeled in green, while no upregulated genes were overexpressed (Fig. 5). Compared with the control group, the average expression values of CCND2, CCNE2, CDKN1C, CDKN2B, ANAPC5, PKMYT1, $C H E K 2$, and PCNA genes in the $10 \mu \mathrm{M}(+)$-terrein-treated group were significantly decreased by 5.52-, 3.30-, 5.32-, 2.24-, $2.52-, 2.52-, 2.31-$, and 2.10 -fold ( $>2$-fold; $\mathrm{P} \leq 0.05$ ), respectively (Table V), and the expression level of the remaining 65 genes was evidently unchanged (data not shown). Eight obviously downregulated genes were visualized in the cell-cycle pathway (Fig. 5). Moreover, the results of flow cytometry (Table IV) indicated that (+)-terrein arrested the cell cycle.

\section{Discussion}

Numerous drugs affect tumorigenesis and tumor growth through several mechanisms, including signal transduction, cell-cycle regulation, apoptosis, telomere biology, angiogenesis and cell senescence $(11,13)$. Most available cancer drugs are antimitotic and act by interfering with the basic mechanism of DNA synthesis and cell division (20). (+)-Terrein inhibited cell growth at various concentrations in various human tumor cell strains (8-10). The $\mathrm{IC}_{50}$ value of (+)-terrein against human breast cancer MCF-7 cells was $1.1 \mathrm{nM}(9)$. The $\mathrm{IC}_{50}$ value was $0.29 \mathrm{mM}$ for HeLa cells (10) and $0.3 \mathrm{mM}$ for NCI-H292 (8). Strese et al (24) observed that the chemosensitivity of various cell lines was differentially expressed, indicating that distinct cell types with distinct genetic backgrounds exhibit distinct responses to drug treatment $(15,25)$.

Since the adhesion and distribution of anchorage-dependent cells are prerequisites for cell viability and proliferation, cell growth and survival also depend on cell morphology (26). Changes in the synthesis and structure of actin induce changes in cell morphology. $\mathrm{FN}$ is a ubiquitous extracellular matrix glycoprotein assembled into an FN matrix in all tissues and 
Table V. Downregulated cell-cycle genes in the Bel-7402 cells treated with (+)-terrein.

\begin{tabular}{lccc}
\hline Gene no. & Gene name & Function in cell cycle & $\mathrm{n}$-fold \\
\hline 1 & $C C N D 2$ & $\mathrm{G}_{1}$ phase and $\mathrm{G}_{1} / \mathrm{S}$ transition & -5.52 \\
2 & $C C N E 2$ & $\mathrm{G}_{1} / \mathrm{S}$ checkpoint & -3.30 \\
3 & $C D K N 1 C$ & Causes arrest of the cell cycle in $\mathrm{G}_{1}$ phase & -5.32 \\
4 & $C D K N 2 B$ & Cell-cycle checkpoint and cell-cycle arrest & -2.24 \\
5 & $A N A P C 5$ & $\mathrm{G}_{2}$ phase and $\mathrm{G}_{2} / \mathrm{M}$ transition & -2.52 \\
6 & $P K M Y T 1$ & Protein kinase, membrane-associated tyrosine/threonine 1 & -2.52 \\
7 & $C H E K 2$ & Checkpoint kinase 2 & -2.31 \\
8 & $P C N A$ & Proliferating cell nuclear antigen & -2.10 \\
\hline
\end{tabular}

Bel-7402 cells treated with $10 \mu \mathrm{M}(+)$-terrein for $48 \mathrm{~h}$ and cells not treated with (+)-terrein served as controls. Each value is the mean of three independent experiments.

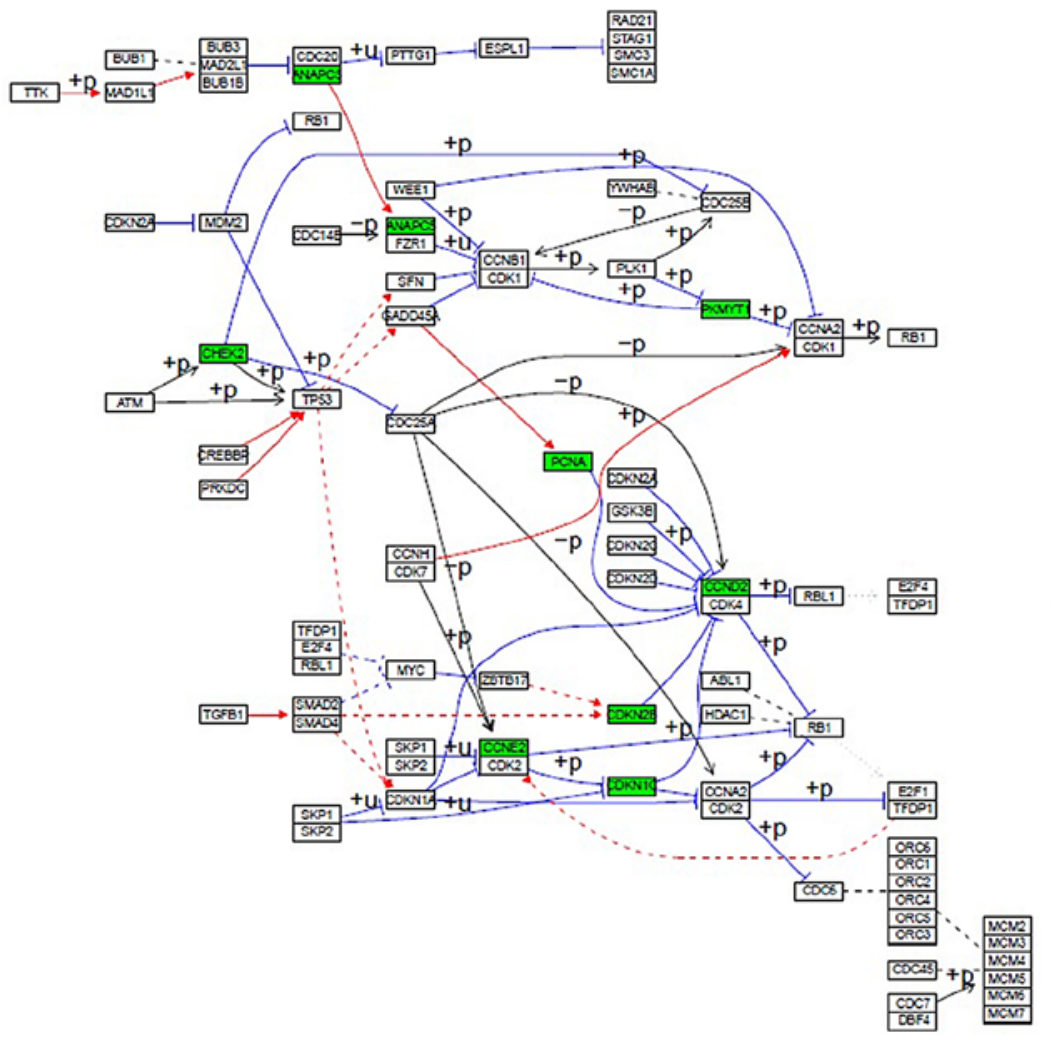

Edge types

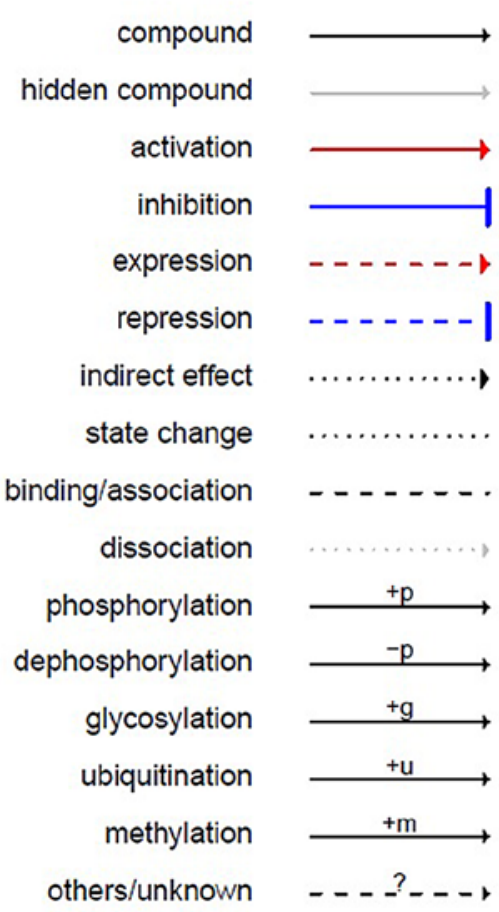

Figure 5. Graphviz view of a cell cycle canonical signaling pathway with gene data. Each box is one gene and the green boxes show the downregulated gene expression of mRNA after the Bel-7402 cells were treated with $10 \mu \mathrm{M}(+)$-terrein $(>2$-fold).

throughout all stages of life. Loss of an FN matrix causes changes in cell morphology, cell signaling, proliferation, and cell-cycle progression $(27,28)$. The aberrant expression of $\mathrm{N}$-cadherin by cancer cells contributes to invasiveness and metastasis by making the cells more motile (29). Vimentin is responsible for maintaining cell shape, adhesion and motility (30).

The inhibitory mechanism of (+)-terrein against the Bel-7402 cell differed from the apoptosis of breast cancer and pulmonary tumor cell lines $(9,10)$. Liao et al (9) and Porameesanaporn et al (10) reported that (+)-terrein suppressed the growth of breast cancer and HeLa cancer cell lines by inducing apoptosis. Demasi et al (8) determined that various ranges of (+)-terrein induced pulmonary tumor cell apoptosis through protease inhibitors.

Kim et al (31) determined that $( \pm)$-terrein inhibited human epidermal keratinocyte proliferation through extracellular signal-regulated protein kinase inactivation and $\mathrm{G}_{2} / \mathrm{M}$ cell-cycle arrest. The fundamental task of the cell cycle is to ensure that DNA is successfully replicated in the $\mathrm{S}$ phase and that the identical chromosomal copies are equally distributed between two daughter cells in the $M$ phase $(32,33)$. Cell proliferation depends on the progression of the cell cycle through the $G_{0} / G_{1}$ phase to the $S$ phase (34). In some biological systems, cell-cycle delay and long-term arrest in the $G_{2}$ phase 
are well documented, but most variation in cell-cycle duration among tissues is due to variability in the length of the $\mathrm{G}_{1}$ phase $(32,33)$. We determined that $(+)$-terrein decreased the proportion of the Bel-7402 cells in the $G_{0} / G_{1}$ and $S$ phases (Table IV). The data suggested that (+)-terrein delayed the progression of the cell cycle. The results indicated that $10 \mu \mathrm{M}$ (+)-terrein inhibited Bel-7402 cell growth (Fig. 2) by arresting the cell cycle in the $\mathrm{G}_{2} / \mathrm{M}$ phase (Table IV). The sensitivity of the drug-induced DNA damage was, not only associated with the interaction between drug and target, but also depended on the dose, time (15) and cellular status (34). The results of this study confirmed that various strains (Bel-7402 and A549) exhibit a distinct response to (+)-terrein (Fig. 2). Therefore, the anti-proliferative mechanism of $(+)$-terrein based on distinct drug doses, time and cellular status remains to be investigated.

Cell-cycle progression in mammalian cells is regulated by various proteins (35). Cell proliferation is closely controlled by positive and negative regulators that determine cell progress throughout the cell cycle (36). The cyclin/cyclin-dependent kinase $(\mathrm{Cdk})$ complexes and Cdk inhibitors (CDKIs) are crucial regulators of cell-cycle progression (37).

Eight genes are related to the cell cycle (Fig. 5). The CCND2 (38), CCNE2 (39), CDKNIC (40) and CDKN2B (41) genes, positively regulated the $\mathrm{G}_{1}$ and $\mathrm{G}_{1} / \mathrm{S}$ phases of the cell cycle, whereas the $A P C$ gene negatively regulated the $\mathrm{G}_{2} / \mathrm{M}$ transition in the cell cycle (42). Distinct cyclins exhibited distinct expression and degradation patterns, which contribute to the temporal coordination of each mitotic event (38). Cyclin D encoded by the $C C N D 2$ gene forms a complex regulatory subunit of CDK4 or CDK6, the activity of which is required for cell-cycle $G_{1} / S$ transition (38). Cyclin E encoded by the CCNE2 gene controls the $\mathrm{G}_{1}$ - to S-phase transition in the cell cycle (39). Cyclin-dependent kinase inhibitor $1 \mathrm{C}$ (p57, Kip2), also known as CDKN1C, causes cell cycle arrest in the $\mathrm{G}_{1}$ phase (40). Cyclin-dependent kinase 4 inhibitor B (ink4b) encoded by the $C D K N 28 B$ gene is a potential factor of cell cycle arrest in the $G_{1}$ phase (41). In addition, anaphase-promoting complex subunit 5 (ANAPC5) consists of at least eight protein subunits, including APC5, CDC27 (APC3; MIM 116946), CDC16 (APC6; MIM 603461), and CDC23 (APC8; MIM 603462). The APC/C targets the mitotic cyclins for degradation, resulting in the inactivation of mitotic cyclin-dependent kinase (M-CdK) complexes, promoting exit from mitosis and cytokinesis (42). Although distinct processes are responsible for this inhibition, a crucial process is the activation of the APC/C by $\mathrm{Cdh} 1$. This continued activation prevents the accumulation of cyclin, which triggers another round of mitosis instead of exiting (42). The results from the multiple mRNA analysis further proved that the Bel-7402 cells were arrested in the $\mathrm{G}_{2} / \mathrm{M}$ phase by $10 \mu \mathrm{M}(+)$-terrein.

Membrane-associated tyrosine- and threonine-specific CDC2-inhibitory kinase encoded by the PKMYT1 gene negatively regulates cell-cycle $\mathrm{G}_{2} / \mathrm{M}$ transition (43). A decrease in the expression of PKMYT1 (Table V) and ANAPC (Fig. 5 and Table V) genes was conducive to arresting the cells in the $\mathrm{G}_{2} / \mathrm{M}$ phase of the cell cycle. The CHEK2 gene provides instructions for producing checkpoint kinase 2 (CHK2). CHEK2 activation in response to DNA damage prevents the cell from entering mitosis (44). Proliferating cell nuclear antigen (PCNA) is a nuclear protein that acts as a processivity factor for DNA polymerase $\varepsilon$ in eukaryotic cells (45). The expression levels of
PCNA varied throughout the cell-cycle progression, and the maximal expression was observed in the $\mathrm{G}_{1}$ and $\mathrm{S}$ phases (46). Furthermore, the PCNA expression level was downregulated as the cells exited the cell cycle and differentiated (47). Based on the PCNA expression level characteristics $(46,47)$, we obtained consistent results indicating that $10 \mu \mathrm{M}(+)$-terrein increased the proportion of treated cells in the $G_{2} / M$ phase (Table IV) and decreased the PCNA expression 2.10-fold, compared with the control group (Table V). Thus, (+)-terrein induced cell cycle arrest by breaking down the balance between multiple gene expressions of the cell cycle.

In conclusion, (+)-terrein exhibited cytotoxicity against the Bel-7402 human hepatoma cell line, yielding an $\mathrm{IC}_{50}$ value of $11.63 \mu \mathrm{M} \pm 0.02$. In addition, (+)-terrein induced round-cell morphology of Bel-7402 and A549 cells but did not induce cell apoptosis. Furthermore, (+)-terrein inhibited Bel-7402 human hepatoma cell proliferation and arrested the cell cycle in the $\mathrm{G}_{2} / \mathrm{M}$ phase by breaking down the expression of the CCND2, CCNE2, CDKN1C, CDKN2B, ANAPC5, PKMYT1, CHEK2 and $P C N A$ cell cycle-related genes. The results suggest that $(+)$-terrein inhibited human tumor cell growth through various strategies. The potential application of $(+)$-terrein remains to be investigated in future studies.

\section{Acknowledgements}

We would like to thank Dr Qian Luo at the Instrument Sharing and Technical Service Platform of SJTU for technical advice on using flow cytometry. We would also like to thank Dr Valliappan Karuppiah for providing assistance with the language. This study was supported by the High-Tech Research and Development Program of China (2011AA090702), the Medical and Engineering Cross Funds of Shanghai Jiao Tong University (YG2011ms13), and the National Natural Science Foundation of China (J1210047 and 31300104).

\section{References}

1. Schütte K, Bornschein J and Malfertheiner P: Hepatocellular carcinoma - epidemiological trends and risk factors. Dig Dis 27: 80-92, 2009.

2. Xie SL, Zhu MG, Lv GY, Zhang Q and Wang GY: The role of RhoC in the proliferation and apoptosis of hepatocellular carcinoma cells. Med Oncol 29: 1802-1809, 2012.

3. Cao H, Phan H and Yang LX: Improved chemotherapy for hepatocellular carcinoma. Anticancer Res 32: 1379-1386, 2012.

4. Nouso K: Current chemotherapies for advanced hepatocellular carcinoma. Clin J Gastroenterol 6: 89-93, 2013.

5. Zhang X, Jia S, Yang S, Yang Y, Yang T and Yang Y: Arsenic trioxide induces $\mathrm{G} 2 / \mathrm{M}$ arrest in hepatocellular carcinoma cells by increasing the tumor suppressor PTEN expression. J Cell Biochem 113: 3528-3535, 2012

6. Raistrick H and Smith G: Studies in the biochemistry of micro-organisms: The metabolic products of Aspergillus terreus Thom. A new mould metabolic product-terrein. Biochem J 29: 606-611, 1935.

7. Arakawa M, Someno T, Kawada M and Ikeda D: A new terrein glucoside, a novel inhibitor of angiogenin secretion in tumor angiogenesis. J Antibiot 61: 442-448, 2008.

8. Demasi M, Felicio AL, Pacheco AO, Leite HG, Lima C and Andrade LH: Studies on terrein as a new class of proteasome inhibitors. J Braz Chem Soc 21: 299-305, 2010.

9. Liao WY, Shen CN, Lin LH, Yang YL, Han HY, Chen JW, Kuo SC, Wu SH and Liaw CC: Asperjinone, a nor-neolignan, and terrein, a suppressor of ABCG2-expressing breast cancer cells, from thermophilic Aspergillus terreus. J Nat Prod 75: 630-635, 2012. 
10. Porameesanaporn Y,Uthaisang-Tanechpongtamb W, Jarintanan F, Jongrungruangchok $\mathrm{S}$ and Thanomsub Wongsatayanon B: Terrein induces apoptosis in HeLa human cervical carcinoma cells through p53 and ERK regulation. Oncol Rep 29: 1600-1608, 2013

11. Anisimov VN: Biology of aging and cancer. Cancer Control 14: 23-31, 2007.

12. Edinger AL and Thompson CB: Death by design: apoptosis, necrosis and autophagy. Curr Opin Cell Biol 16: 663-669, 2004.

13. Gibbs JB: Mechanism-based target identification and drug discovery in cancer research. Science 287: 1969-1973, 2000.

14. Bergers $\mathrm{G}$ and Benjamin LE: Tumorigenesis and the angiogenic switch. Nat Rev Cancer 3: 401-410, 2003.

15. Schmitt CA and Lowe SW: Apoptosis and therapy. J Pathol 187: 127-137, 1999.

16. Xiao L, Yin Y, Sun W, Zhang F and Zhang F and Li Z: Enhanced production of (+)-terrein by Aspergillus terreus strain PF26 with epigenetic modifier suberoylanilide hydroxamic acid. Proc Biochem 48: 1635-1639, 2013.

17. Xu B, Yin Y, Zhang F, Li Z and Wang L: Operating conditions optimization for (+)-terrein production in a stirred bioreactor by Aspergillus terreus strain PF-26 from marine sponge Phakellia fusca. Bioprocess Biosyst Eng 35: 1651-1655, 2012.

18. Yin Y, Gao Q, Zhang F and Li Z: Medium optimization for the high yield production of single (+)-terrein by Aspergillus terreus strain PF-26 derived from marine sponge Phakellia fusca. Process Biochem 47: 887-891, 2012.

19. Yin Y, Xu B, Li Z and Zhang B: Enhanced production of (+)-terrein in fed-batch cultivation of Aspergillus terreus strain PF-26 with sodium citrate. World J Microbiol Biotechnol 29 . 441-446, 2013.

20. Schmittgen TD and Livak KJ: Analyzing real-time PCR data by the comparative C(T) method. Nat Protoc 3: 1101-1108, 2008.

21. Evan GI and Vousden KH: Proliferation, cell cycle and apoptosis in cancer. Nature 411: 342-348, 2001.

22. Kanehisa M and Goto S: KEGG: Kyoto encyclopedia of genes and genomes. Nucleic Acids Res 28: 27-30, 2000.

23. Luo W and Brouwer C: Pathview: an R/Bioconductor package for pathway-based data integration and visualization. Bioinformatics 29: 1830-1831, 2013.

24. Strese S, Fryknäs M, Larsson R and Gullbo J: Effects of hypoxia on human cancer cell line chemosensitivity. BMC Cancer 13 $331,2013$.

25. Evan G and Littlewood T: A matter of life and cell death. Science 281: 1317-1322, 1998.

26. French PW, Donnellan M and McKenzie DR: Electromagnetic radiation at $835 \mathrm{MHz}$ changes the morphology and inhibits proliferation of a human astrocytoma cell line. Bioelectrochem Bioenerg 43: 13-18, 1997.

27. Bourdoulous S, Orend G, MacKenna DA, Pasqualini R and Ruoslahti E: Fibronectin matrix regulates activation of RHO and CDC42 GTPases and cell cycle progression. J Cell Biol 143: 267-276, 1998

28. Yi M and Ruoslahti E: A fibronectin fragment inhibits tumor growth, angiogenesis, and metastasis. Proc Natl Acad Sci USA 98: 620-624, 2001

29. Ramis-Conde I, Chaplain MAJ, Anderson ARA and Drasdo D: Multi-scale modelling of cancer cell intravasation: the role of cadherins in metastasis. Phys Biol 6: 016008, 2009.
30. Mendez MG, Kojima S and Goldman RD: Vimentin induces changes in cell shape, motility, and adhesion during the epithelial to mesenchymal transition. FASEB J 24: 1838-1851, 2010.

31. Kim DS, Lee HK, Park SH, Lee S, Ryoo IJ, Kim WG, Yoo ID, Na JI, Kwon SB and Park KC: Terrein inhibits keratinocyte proliferation via ERK inactivation and G2/M cell cycle arrest. Exp Dermatol 17: 312-317, 2008.

32. Heichman KA and Roberts JM: Rules to replicate by. Cell 79: 557-562, 1994.

33. Nilsson I and Hoffmann I: Cell cycle regulation by the $\mathrm{Cdc} 25$ phosphatase family. Prog Cell Cycle Res 4: 107-114, 2000.

34. Gonzalez VM, Fuertes MA, Alonso C and Perez JM: Is cisplatin-induced cell death always produced by apoptosis? Mol Pharmacol 59: 657-663, 2001.

35. Sherr CJ: Cancer cell cycles. Science 274: 1672-1677, 1996.

36. Brooks $\mathrm{G}$ and La Thangue NB: The cell cycle and drug discovery: the promise and the hope. Drug Discov Today 4: 455-464, 1999.

37. Nurse P: A long twentieth century of the cell cycle and beyond. Cell 100: 71-78, 2000

38. Mullany LK, White P, Hanse EA, Nelsen CJ, Goggin MM, Mullany JE, Anttila CK, Greenbaum LE, Kaestner KH and Albrecht JH: Distinct proliferative and transcriptional effects of the D-type cyclins in vivo. Cell Cycle 7: 2215-2224, 2008.

39. Lauper N, Beck AR, Cariou S, Richman L, Hofmann K, Reith W, Slingerland JM and Amati B: Cyclin E2: a novel CDK2 partner in the late $\mathrm{G} 1$ and $\mathrm{S}$ phases of the mammalian cell cycle. Oncogene 17: 2637-2643, 1998 .

40. Matsuoka S, Edwards MC, Bai C, Parker S, Zhang P, Baldini A, Harper JW and Elledge SJ: p57KIP2, a structurally distinct member of the p21CIP1 Cdk inhibitor family, is a candidate tumor suppressor gene. Genes Dev 9: 650-662, 1995.

41. Hannon GJ and Beach D: pl5INK4B is a potential effector of TGF-beta-induced cell cycle arrest. Nature 371: 257-261, 1994.

42. Kraft C, Herzog F, Gieffers C, Mechtler K, Hagting A, Pines J and Peters JM: Mitotic regulation of the human anaphase-promoting complex by phosphorylation. EMBO J 22: 6598-6609, 2003.

43. Liu F, Rothblum-Oviatt C, Ryan CE and Piwnica-Worms $\mathrm{H}$ : Overproduction of human Myt1 kinase induces a G2 cell cycle delay by interfering with the intracellular trafficking of Cdc2-cyclin B1 complexes. Mol Cell Biol 19: 5113-5123, 1999.

44. Cybulski C, Górski B, Huzarski T, Masojć B, Mierzejewski M, Debniak T, Teodorczyk U, Byrski T, Gronwald J, Matyjasik J, Złowocka E, Lenner M, Nej K, Castaneda J, Medrek K, Szymańska A, Szymańska J, Kurzawski G, Suchy J, Oszurek O, Witek A, Narod SA and Lubinski J: CHEK2 is a multiorgan cancer susceptibility gene. Am J Hum Genet 75: 1131-1135, 2004.

45. Kisielewska J, Lu P and Whitaker M: GFP-PCNA as an S-phase marker in embryos during the first and subsequent cell cycles. Biol Cell 97: 221-229, 2005

46. Kumar D, Minocha N, Rajanala K and Saha S: The distribution pattern of proliferating cell nuclear antigen in the nuclei of Leishmania donovani. Microbiology 155: 3748-3757, 2009.

47. Barton KM and Levine EM: Expression patterns and cell cycle profiles of PCNA, MCM6, cyclin D1, cyclin A2, cyclin B1, and phosphorylated histone $\mathrm{H} 3$ in the developing mouse retina. Dev Dynam 237: 672-682, 2008. 